\title{
Generic assumption vs. empirical model in stem carbon prediction of Eucalyptus grandis Wall ex. Maiden
}

\author{
W.A.R.T.W. Bandara* and A.M.H.L. Aththanayake \\ Department of Zoology and Environmental Management, Faculty of Science, University of Kelaniya, Kelaniya.
}

\begin{abstract}
According to the generic assumption in carbon (C) estimation, $50 \%$ of dry stem biomass is considered as carbon. Since some species deviate from the general carbon estimation rule, attention should be paid to understand the magnitude of deviation before applying the general rule. South East Asian region forest plantations widely use Eucalyptus grandis. This study was undertaken to test the general rule and to construct a model in prediction of stem carbon of E. grandis. Stem core samples of 144 individuals selected from different climatic zones in Sri Lanka were analysed by loss-on-ignition method to estimate the total carbon content in the stem. There is a significant difference between actual and assumed carbon content. Therefore, a model was constructed using multiple linear regression to predict carbon content in E. grandis stems and it is able to predict up to $98.2 \%$ reliability. This study concluded that the assumed stem carbon content, which is based on the assumption that $50 \%$ of plant biomass is carbon, has a significant difference from the actual stem carbon content, while the predicted stem carbon content using the constructed model is not significantly different from the actual stem carbon content. The findings also revealed that the average stem carbon content of $E$. grandis is $64 \%$ proving the inaccuracy of using the rule of ' $50 \%$ of dry stem biomass is carban' and appropriateness of the constructed model, which suggests that the average stem carbon content of E. grandis is $62 \%$. Results of this study can be used in carbon estimations and policy making in carbon estimations.
\end{abstract}

Keywords: Above-ground carbon, carbon sequestration, Eucalyptus grandis, forest plantations, stem biomass.

\section{INTRODUCTION}

The world's natural forests have been estimated to contain up to $80 \%$ of all above-ground terrestrial carbon
(Dixon et al., 1994). However, increase of deforestation due to anthropogenic activities, especially in the tropics, has led to the overall negative carbon exchange between forests and atmosphere, thus reducing the global warming mitigation potential of forests by deviating from a global carbon sink to a net carbon source (Brown \& Lugo, 1992; Clark, 2002; Lewis, 2006). Drastic reduction of natural dense forest cover in many parts of the world has resulted due to high demand for forest products such as timber, non-timber forest products and fuel wood, population growth along with urbanisation and industrialisation, agricultural expansion, overgrazing, human induced forest fires, mining and landuse changes (Hall \& Bawa, 1993; Geist \& Lambin, 2002; Subasinghe, 2007; Chakravarty et al., 2012).

In order to meet this accelerated demand on certain forest resources a number of afforestation and reforestation programmes have been implemented worldwide. In the Sri Lankan context, the Forest Department of Sri Lanka has introduced plantation forestry with many local and exotic fast-growing tree species (Subasinghe, 2007; Abayakoon et al., 2009; Markandu, 2009). Fast-growing tree species are preferred as they accumulate a higher amount of biomass than slow growing species during a particular time period, which in turn provide high timber yield (Moura-Costa, 1996). The major timber species used in plantation forestry in the South Asian region including Sri Lanka are Swetenia macrophylla (Mahogany), Tectona grandis (Teak), Pinus carrebia and $P$. radiata (Pines), Acasia auriculaformis (Acacia) and Eucalyptus spp. According to latest available statistics, the total estimated monoculture

\footnotetext{
*Corresponding author (rangika@kln.ac.lk; iD https://orcid.org/0000-0002-2080-9347)
} 
carbon stock in Sri Lanka accounted to 4.23 million tonnes in an area of $57,618.8$ ha and $89 \%$ of this is contributed by P. caribaea (44\%), T. grandis (21\%), Eucalyptus grandis (11\%), E. camaldulensis (7\%) and S. macrophylla (6\%) (De Costa \& Suranga, 2012). The total carbon stock in mixed cultures amounted to 0.681 million tonnes in 5,949.6 ha, $55 \%$ of which was accounted by E. robusta and E. grandis (17\%), Pinus mixed (13\%), E. grandis and E. microcorys $(12.5 \%)$, Eucalyptus mixed (7\%), and Acacia mangium and Acacia auriculiformis (5 \%) (De Costa \& Suranga, 2012). In order to select tree species to optimise benefits by obtaining maximum timber yield and to mitigate climate change, better understanding of the species, their wood properties as well as carbon sequestration capability in a given climate-ecological condition is required. Thomas and Martin (2012) suggested the need of finding information on wood carbon content in different tree species across different forest types. Also, according to Thomas and Martin (2012) the live wood carbon content (expressed as a percentage of wood dry mass) was highly variable among tropical hardwood species. However, carbon sequestration potential of planted tree species has not been given sufficient attention by policy makers, foresters and scientists especially in the Asian region, irrespective of their high contribution to mitigate global climate change (De Costa \& Suranga, 2012).

According to a study carried out in Eucalypt woodlands with an area of 27 Mha in Queensland, Australia, above- and below-ground biomass of $18 \mathrm{Mt} \mathrm{C} \mathrm{y}^{-1}$ was estimated, which was a significant contribution to the global terrestrial carbon sink (Burrows et al., 2002). A study carried out by Keith et al. (2009) showed that an evergreen temperate forest dominated by Eucalyptus regnans in the moist temperate region of the Central Highlands of Victoria, Australia had the highest known biomass carbon density in the world with an average of $1,053 \mathrm{tC} \mathrm{ha}^{-1}$ in living above-ground biomass. At present, the Forest Department of Sri Lanka is carrying out harvesting regimes for many state timber plantations, especially in the upcountry, and considering certain species for replanting. Due to the important role played by $E$. grandis in sequestering carbon globally, regionally and specifically locally, this species was selected as the test species for the present study.

Carbon trading could be used to make reforestation profitable as well as to expand the forest area of a given geographical area (Markandu, 2009). In this instance, quantification of net carbon stock of the plantation species is an important piece of information in deducting the carbon credit of forest plantations. Generally, quantification of above-ground carbon has received more attention than below-ground carbon (West, 2009). Moreover, research attention has also been given to estimate whole tree carbon rather than the amount of carbon stored in different parts of the tree. At present, the commonly adopted method of carbon quantification is that the generic assumption of $50 \%$ of above-ground plant biomass is carbon on dry weight basis other than the biomass carbon conversion factor of $49 \%$ adopted by IPCC for tropical and subtropical tree species (Thomas $\&$ Martin, 2012). However, this amount may greatly vary from species to species and also in different parts of an individual tree (Sampson, 1992; West, 2009; Thomas \& Martin, 2012). Past studies have shown that in general the amount of carbon stored in stem wood of different Eucalyptus spp. are; E. obliqua $-50 \%$ and E. pilularis - 51 \% (Ximenes et al., 2008; Ribeiro et al., 2015). However, in general for other tree species including other Eucalyptus spp. the above-ground plant biomass in tree parts or as a whole is estimated based on the assumption of $50 \%$ of plant biomass is carbon (West, 2009).

Several authors have reviewed allometric relationships, relationship which relate a part of an organism to whole, in estimating biomass and carbon in plants (Chave et al., 2005; Montagu et al., 2005; Vieilledent et al., 2012; Chave et al., 2014). In such instances, many attempts have been made for a particular species for a given locality or for species over a wide geographical range (West, 2009). The present study was carried out with the primary objective of evaluating the accuracy of applying the general assumption of $50 \%$ of stem wood biomass would be carbon for E. grandis grown in South Asia. As the secondary objective, an attempt was made to develop an empirical model to predict the stem wood carbon content of $E$. grandis. This will help to estimate the value addition for $E$. grandis wood by precisely estimating the amount of carbon stored in a unit volume of wood.

\section{METHODOLOGY}

\section{Study area}

Since E. grandis is confined to the upcountry, Intermediate Zone and Wet Zone of Sri Lanka 4 E. grandis plantations were selected from Nuwara Eliya (Kandapola and Bogawanthalawa), Badulla (Haputhale) and Rathnapura (Pinnawala) Districts to represent these zones. Characteristics and details of the study sites are summarised in Table 1, and Figure 1 illustrates the locations of the study sites. 
Table 1: Characteristics and details of the study sites

\begin{tabular}{|c|c|c|c|c|c|c|}
\hline Site & Agro-ecological zone & $\begin{array}{l}\text { Annual rainfall } \\
(\mathrm{mm})\end{array}$ & $\begin{array}{l}\text { Temperature } \\
\left({ }^{\circ} \mathrm{C}\right)\end{array}$ & Soil type & $\begin{array}{l}\text { Age } \\
\text { (Year) }\end{array}$ & $\begin{array}{l}\text { Area } \\
\text { (ha) }\end{array}$ \\
\hline Kandapola & $\begin{array}{l}\text { Wet Zone - up country } \\
\left(\mathrm{WU}_{3}\right)\end{array}$ & $3000-4000$ & $17-20$ & $\begin{array}{l}\text { Red-yellow podzolic soils } \\
\text { with dark B horizon and } \\
\text { red-yellow podzolic soils } \\
\text { with prominent A1 horizon }\end{array}$ & 16 & 28.5 \\
\hline Bogawanthalawa & $\begin{array}{l}\text { Wet Zone - up country } \\
\left(\mathrm{WU}_{2}\right)\end{array}$ & $2500-3000$ & $17-20$ & $\begin{array}{l}\text { Red-yellow podzolic soils } \\
\text { and mountain regosols }\end{array}$ & 20 & 37.9 \\
\hline Haputale & $\begin{array}{l}\text { Intermediate Zone - up country } \\
{\left[\mathrm{I}\left(\mathrm{U}_{2}-\mathrm{U}_{3}\right)\right]}\end{array}$ & $2500-3000$ & $17-20$ & $\begin{array}{l}\text { Red-yellow podzolic soils } \\
\text { and mountain regosols }\end{array}$ & 36 & 15.0 \\
\hline Pinnawala & $\begin{array}{l}\text { Wet Zone - mid country } \\
\left(\mathrm{WM}_{3}\right)\end{array}$ & $1500-2000$ & $20-22$ & $\begin{array}{l}\text { Reddish brown latosolic soils, } \\
\text { immature brown loams and } \\
\text { red-yellow podzolic soils }\end{array}$ & 21 & 11.0 \\
\hline
\end{tabular}

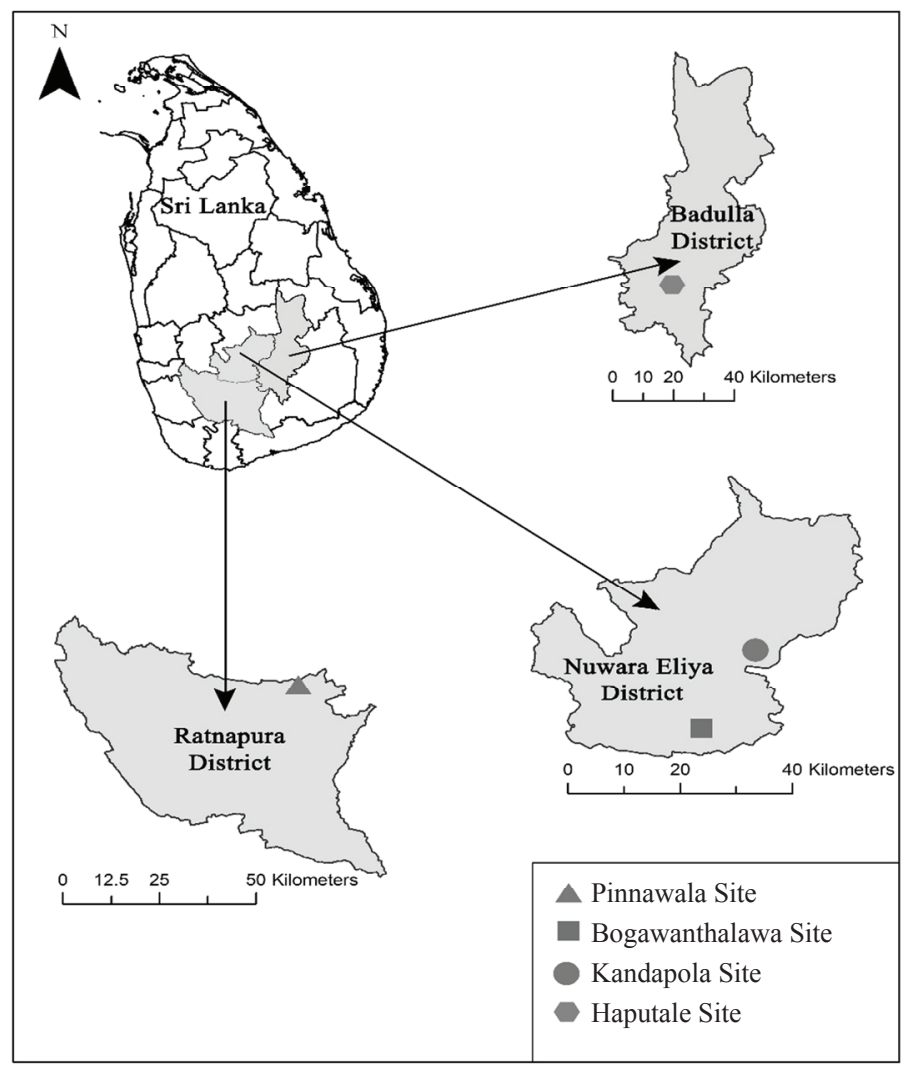

Figure 1: Map of the study sites

\section{Sampling}

The selected plantations were divided into 3 strata; valley, slope and ridge-top based on their similar topographical variations. Representing each stratum, three 0.05 ha circular sample plots were laid out in each plantation. The procedure was repeated for all 4 plantations, hence 12 sample plots were taken into consideration for this 
study. On average there were about $12(6-18)$ individual trees in a plot and altogether 141 individuals were considered as sampling units.

Stem core samples at $1.3 \mathrm{~m}$ above the forest floor were extracted from the selected trees using an increment borer with $20 \mathrm{~cm}$ length, $5 \mathrm{~cm}$ core diameter and 2 threading in order to estimate the stem carbon content. Total tree height and tree canopy height was measured using the clinometer. Diameter tape was used to measure the diameter at breast height (dbh).

\section{Estimation of stem carbon}

Green volumes $\left(\mathrm{V}_{\mathrm{C}}\right)$ of the collected stem core samples were measured using the Archimedes principle. The carbon content of each stem core sample was estimated using loss-on-ignition method (Chavan \& Rasal, 2010; Al-Amin \& Ullah, 2012) and all the readings including volume and weight were taken at room temperature.

The carbon content of each stem core sample was measured using equation 1 .

$\mathrm{C}_{\mathrm{C}}=\left(\mathrm{W}_{2}-\mathrm{W}_{1}\right)-\left(\mathrm{W}_{3}-\mathrm{W}_{1}\right)$

where,

$\mathrm{C}_{\mathrm{C}}=$ Carbon content of the core $(\mathrm{g})$

$\mathrm{W}_{1}=$ Weight of the crucible $(\mathrm{g})$

$\mathrm{W}_{2}=$ Weight of the sample after oven-dry $(\mathrm{g})+\mathrm{W}_{1}$

$\mathrm{W}_{3}=$ Weight of the sample after ignition $(\mathrm{g})+\mathrm{W}_{1}$

Carbon content of the entire stem was estimated using equation 2 (Munasinghe \& Subasinghe, 2011).

$\mathrm{C}_{\mathrm{S}}=\mathrm{C}_{\mathrm{C}} / \mathrm{V}_{\mathrm{C}} \times \mathrm{V}_{\mathrm{m}}$

where,

$\mathrm{C}_{\mathrm{S}}=$ Carbon content of the stem (amount of total carbon per stem) $(\mathrm{kg})$

$\mathrm{C}_{\mathrm{C}}=$ Carbon content of the core $(\mathrm{kg})$

$\mathrm{V}_{\mathrm{m}}=$ Merchantable wood volume $\left(\mathrm{m}^{3}\right)$

$\mathrm{V}_{\mathrm{C}}=$ Green volume of the core $\left(\mathrm{m}^{3}\right)$

The merchantable wood volume $\left(\mathrm{V}_{\mathrm{m}}\right)$ of each tree was calculated using volume function (equation 3) (Anon, 1996), which is being used by the Forest Department, Sri Lanka, to estimate merchantable wood volume for E. grandis.

$$
\begin{gathered}
\mathrm{V}_{\mathrm{m}}=[0.337277-(0.151178 / \pi(\mathrm{dbh}))] \\
\times\left(\pi(\mathrm{dbh})^{2} \mathrm{~h} / 40000\right)
\end{gathered}
$$

where,

$\mathrm{V}_{\mathrm{m}}=$ Merchantable wood volume $\left(\mathrm{m}^{3}\right)$

$\mathrm{dbh}=$ Diameter at breast height $(\mathrm{cm})$

$\mathrm{h} \quad=$ Total tree height $(\mathrm{m})$

\section{Comparison of actual and assumed stem carbon content}

The actual carbon content of the stem estimated through laboratory experiment $\left(\mathrm{C}_{\text {actual }}\right)$, and the assumed carbon content of the stem obtained based on the assumption that $50 \%$ of biomass is carbon $\left(\mathrm{C}_{\text {assumed }}\right)$ were compared using student's t-test.

\section{Model construction}

\section{Theory behind the model}

The carbon content of a tree is a function of the biomass of the tree (West, 2009).

Carbon content of a tree $=\mathrm{f}[$ Biomass $]$

This study focuses on the stem carbon content. The biomass of the tree stem can be determined using the specific gravity and the volume of the tree (Miles \& Smith, 2009).

Biomass of a stem $=\mathrm{f}[$ Specific gravity, volume ]

Specific gravity can be determined using the age of the tree, and age of the tree can be represented by tree height and tree diameter at dbh (De Castro et al., 1993).

Specific gravity $=\mathrm{f}[$ Age $]$

Age $=\mathrm{f}[$ Height, dbh ]

Considering the form factor, volume of the stem can also be determined as a function of different tree heights such as total tree height and canopy height, dbh of tree and tree basal area (Muukkonen, 2007).

Volume $=\mathrm{f}[$ Total tree height, canopy height, dbh, tree basal area]

Therefore, finally stem carbon content can be determined as a function of different tree heights, dbh of tree and tree basal area.

Stem carbon content $=\mathrm{f}[$ Total tree height, canopy height, $\mathrm{dbh}$, tree basal area] 


\section{Calculation of tree basal area}

Tree basal area is the cross-sectional area of a tree's trunk at breast height (Wilson, 2007). Tree basal area is calculated using equation 4 .

$\mathrm{g}=\pi(\mathrm{dbh})^{2} / 40000$

where,

$\mathrm{g}=$ Tree basal area $\left(\mathrm{m}^{2}\right)$

$\mathrm{dbh}=$ Diameter at breast height $(\mathrm{cm})$

Regression analysis was performed using statistical software MINITAB 14 to construct the model. In model construction, stem carbon content in $\mathrm{kg}$ was considered as the dependent variable while $\mathrm{dbh}$ in $\mathrm{cm}$, total tree height and canopy height in $\mathrm{m}$ and basal area in $\mathrm{m}^{2}$ were considered as explanatory variables. In order to select appropriate explanatory variables to be included in the model, Pearson correlation was performed and dependent variable was plotted against each selected explanatory variable.

In model construction, there should not be a relationship among the selected explanatory variables, and one variable cannot be linearly predicted from the others. If the selected explanatory variables are related, it causes the multicollinearity effect. Therefore, relationships between explanatory variables were checked through plotting graphs of total tree height against dbh and basal area (Figures $2 \mathrm{~A}$ and $2 \mathrm{~B}$ ).

According to the graph between total tree height and dbh (Figure 2A) steep slope indicates young trees, which are still sorting out dominance and prefer to increase height than $\mathrm{dbh}$, while shallow or flat slope indicates mature trees, which have already achieved dominance, and prefer to increase dbh than height. Therefore, in order to obtain a more precise model both $\mathrm{dbh}$ and total tree height were taken as explanatory variables in model construction.

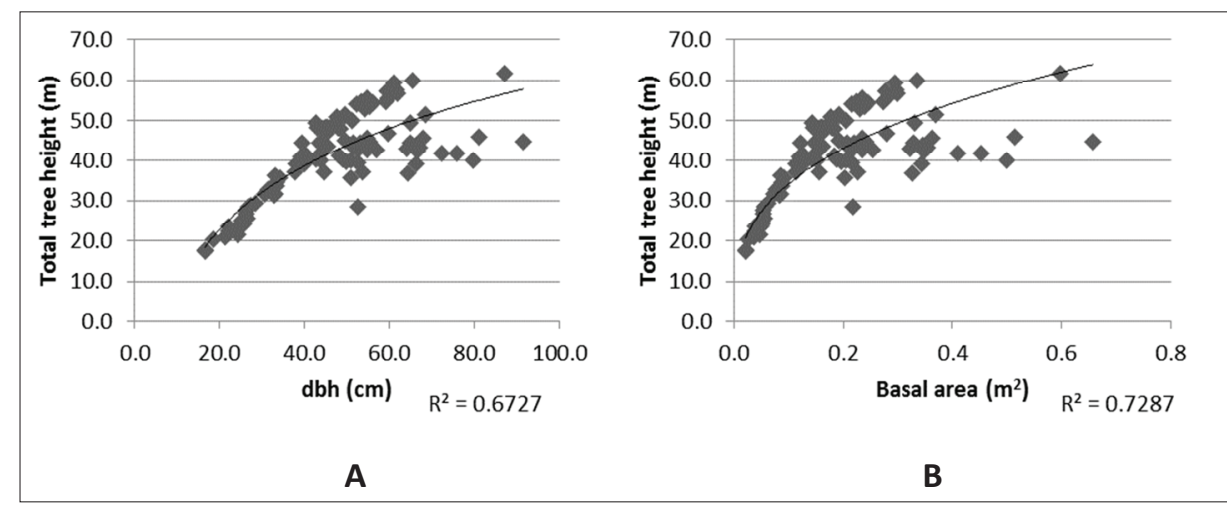

Figure 2: Graphs between total tree height and dbh (A); total tree height and basal area (B)

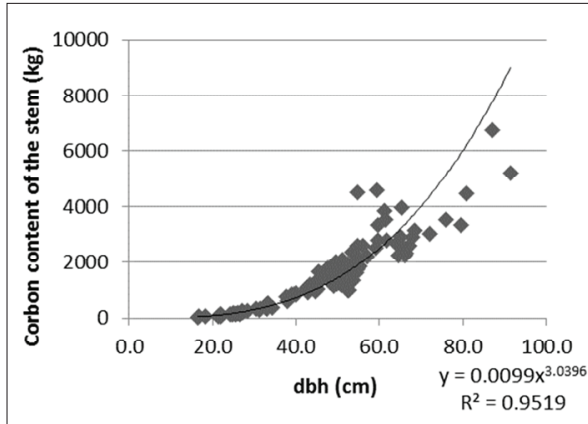

A

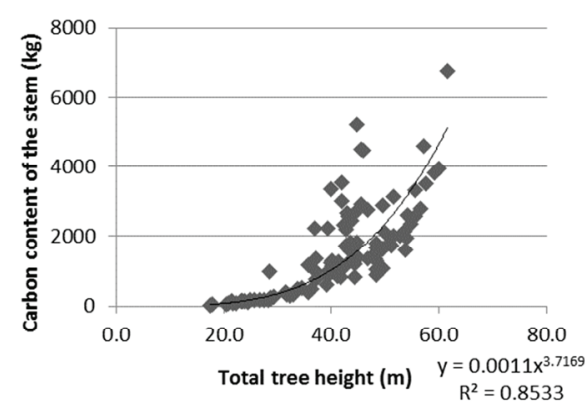

B

Figure 3: Distribution of the carbon content of stem with dbh (A) and total tree height (B) 
According to Figure 2B, the relationship between total tree height and basal area also has a non-linear relationship where the steep slope is represented by young trees and the flat slope is represented by mature trees. Therefore, both basal area and total tree height were also taken as explanatory variables in model construction.

Stem carbon content was calculated based on the volume of the tree stem. Volume of tree stem increases three dimensionally whereas length (height and dbh) increases one dimensionally. As weight and volume are related, weight of the stem also increases three dimensionally. Length and weight are significantly related and has a curvilinear relationship. This relationship is clearly seen in distribution of the carbon content of stem with dbh and total tree height (Figure 3).

Therefore, when a tree grows linearly as increasing height or dbh, the other two dimensions also increases, increasing the volume (as well as weight of carbon) of the tree.

$\mathrm{W}=\mathrm{aL}^{\mathrm{b}}$

where;

$\mathrm{W}=$ Weight

$\mathrm{L}=$ Length

When $\mathrm{b}=3$, it implies that three dimensions are grown at the same rate, which is known as 'isometric growth' and when $b \neq 3$, it implies that three dimensions are not grown at the same rate, which is known as 'allometric growth'.

As the obtained values for (b) in two equations, for $\mathrm{dbh}$ and total tree height are 3.039 and 3.716, respectively, it implies that the trees show allometric growth.

The most commonly used expression for the relationship corresponding to the allometric growth, where weight is expressed in terms of length, is linear regression (in this study multiple regression as y variable was estimated using two $\mathrm{x}$ variables) of log-transformed data. This transformation has the advantage, which tends to stabilise the variance of weight as the variability in weight usually increases with length. Also, it is easier to obtain a linear relationship through log transformation.

After data were transformed into log values, scatter plots were observed (Figure 4). According to the graphs both have high $\mathrm{R}^{2}$ values as 0.950 and 0.852 for $\log$ carbon content of stem with $\log \mathrm{dbh}$ and $\log$ carbon content of stem with log total tree height, respectively.
Models were constructed using MINITAB 14 statistical software as following combinations of $\mathrm{x}$ variables.

Stem carbon $=\mathrm{f}(\mathrm{dbh}$, total tree height $)$

Stem carbon $=\mathrm{f}$ (basal area, total tree height $)$

For model validation, $25 \%$ of collected data were retained untouched while using $75 \%$ of data in model construction. Regression analysis was conducted in model construction with the probability level of $95 \%$. For qualitative analysis, at $95 \%$ probability level $p$ values and $\mathrm{R}^{2}$ values were examined and residual diagrams were observed. For quantitative analysis, model bias value and modelling efficiency value were tested (Soares et al., 1995; Mason et al., 2006). By evaluating these parameters the best fitted model was selected.

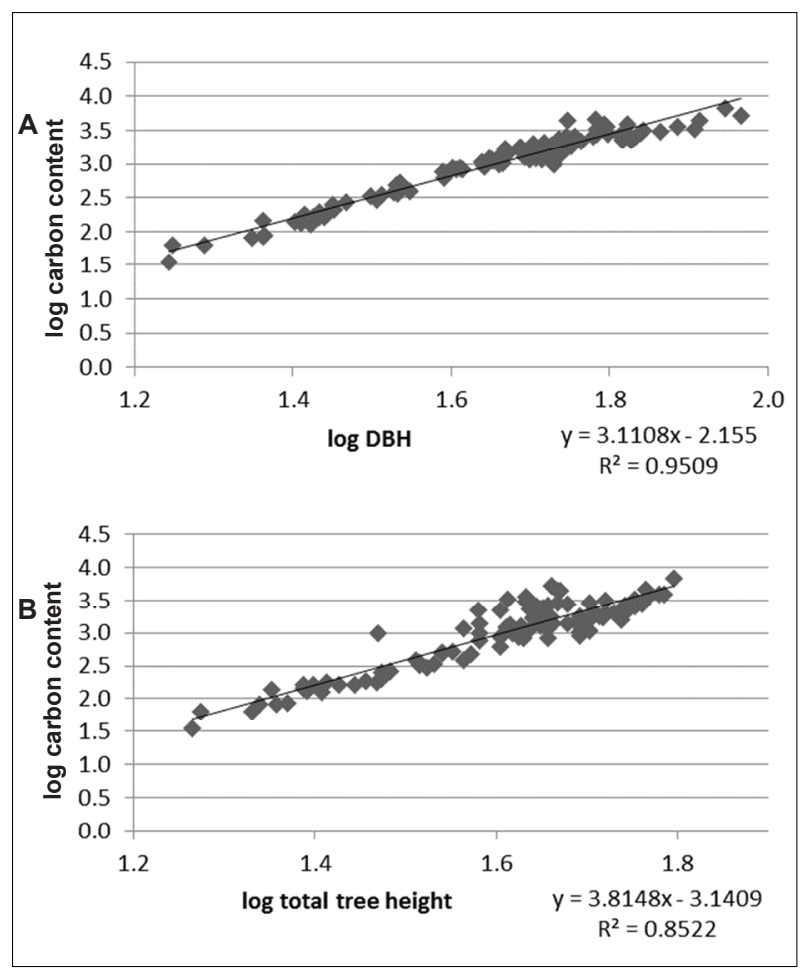

Figure 4: Distribution of the carbon content of stem with dbh (A) and total tree height (B) after log transformation

Validation of the selected model was conducted using the reserved $25 \%$ data (Rykiel, 1996; Pandey et al., 1999). From the total sample, every fourth sample was reserved in order to use in the validation process. The normal residuals were calculated. Then the scatter plots of residual versus actual values were observed to assess whether residuals were randomly distributed. 
Then the predicted carbon content of the stem obtained using the constructed model was compared with actual and assumed carbon contents of the stem using one way ANOVA followed by Tukey's pairwise comparison.

\section{RESULTS AND DISCUSSION}

\section{Comparison of actual and assumed stem carbon content}

It was found that $\mathrm{C}_{\text {actual }}$ was significantly higher than $\mathrm{C}_{\text {assumed }}(\mathrm{p}<0.05)$ showing that $\mathrm{C}_{\text {assumed }}$ gives an underestimate of the stem carbon content in $E$. grandis. Boxplot of actual carbon content and assumed carbon content is illustrated in Figure 5. Also, $85.8 \%$ of the collected samples have given higher $\mathrm{C}_{\text {actual }}$ than $\mathrm{C}_{\text {assumed }}$ and an average stem carbon content of $64 \%$. Hence, $\mathrm{C}_{\text {assumed }}$ is negatively biased.

\section{Model construction}

According to the obtained Pearson correlation values, the stem carbon content showed good correlation with dbh (0.908), total tree height $(0.748)$ and basal area (0.919) while a weak correlation with canopy height (0.294). Also, according to the scatter plots, the stem carbon content showed positive correlation with dbh $\left(\mathrm{R}^{2}=0.9519\right.$; Figure 6A), total tree height $\left(\mathrm{R}^{2}=0.8533\right.$; Figure $6 \mathrm{~B})$ and tree basal area $\left(\mathrm{R}^{2}=0.9519\right.$; Figure 6C) while a weak correlation with canopy height (Figure 6D).

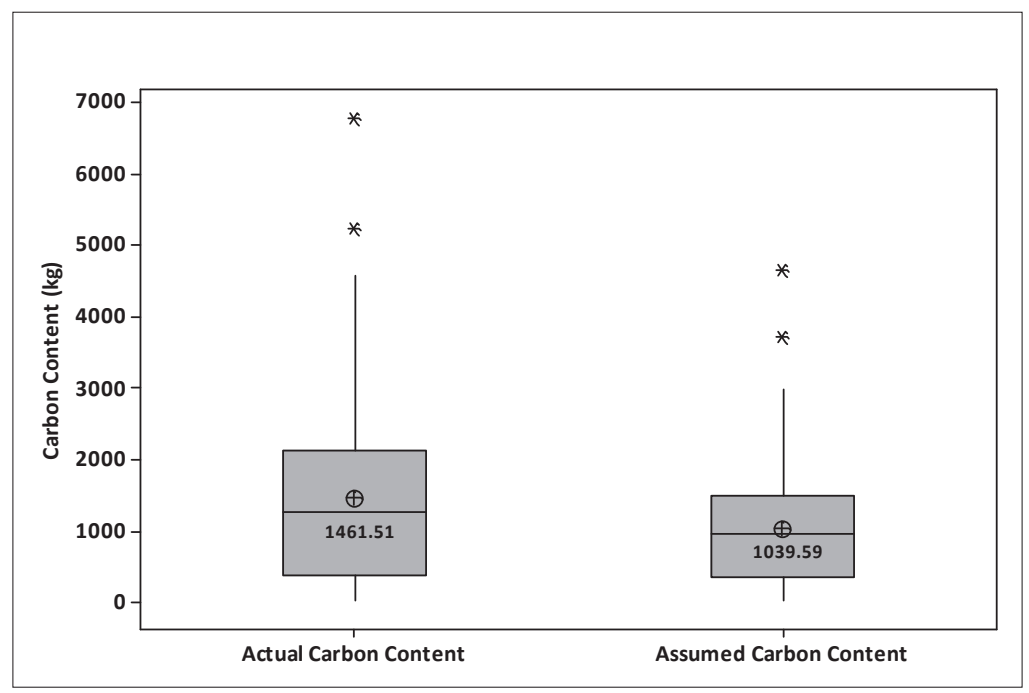

Figure 5: Boxplot of actual carbon content and assumed carbon content. T-value $=3.42$, $\mathrm{DF}=280, \mathrm{SE} ;$ actual carbon content $=104 \mathrm{~kg}$, assumed carbon content $=67 \mathrm{~kg}$

According to the scatter plots of total tree height against $\mathrm{dbh}$ and basal area, they were found to be not interrelated. It was also shown that they could not be linearly predicted from each other, hence were selected as explanatory variables of stem carbon, which were multiply correlated with high significance (Table 2). As stem carbon had ln-ln relationships with individual explanatory variables of dbh, total tree height (tth) and tree basal area (g) (Figure 6) with high $\mathrm{R}^{2}$ values, the nature of the two multiple regression relationships (model 1 and model 2) (Table 2) are justifiable.

\section{Model evaluation}

According to residual diagrams of model 1 and model 2 which were used for model evaluation, model 1 showed a random pattern indicating a good fit for the regression model (Figure 7), and model 2 showed inverted U shaped or non-random pattern indicating an improper fit of the regression model (Figure 8).

Therefore, model 1 was selected as the best model to predict stem carbon of E. grandis. Further, model 1 was 
assessed for model bias and modelling efficiency values. In the selected model, model bias value $(0.0015)$ is closer to zero and modelling efficiency value (0.982) is closer to one indicating a better fit.

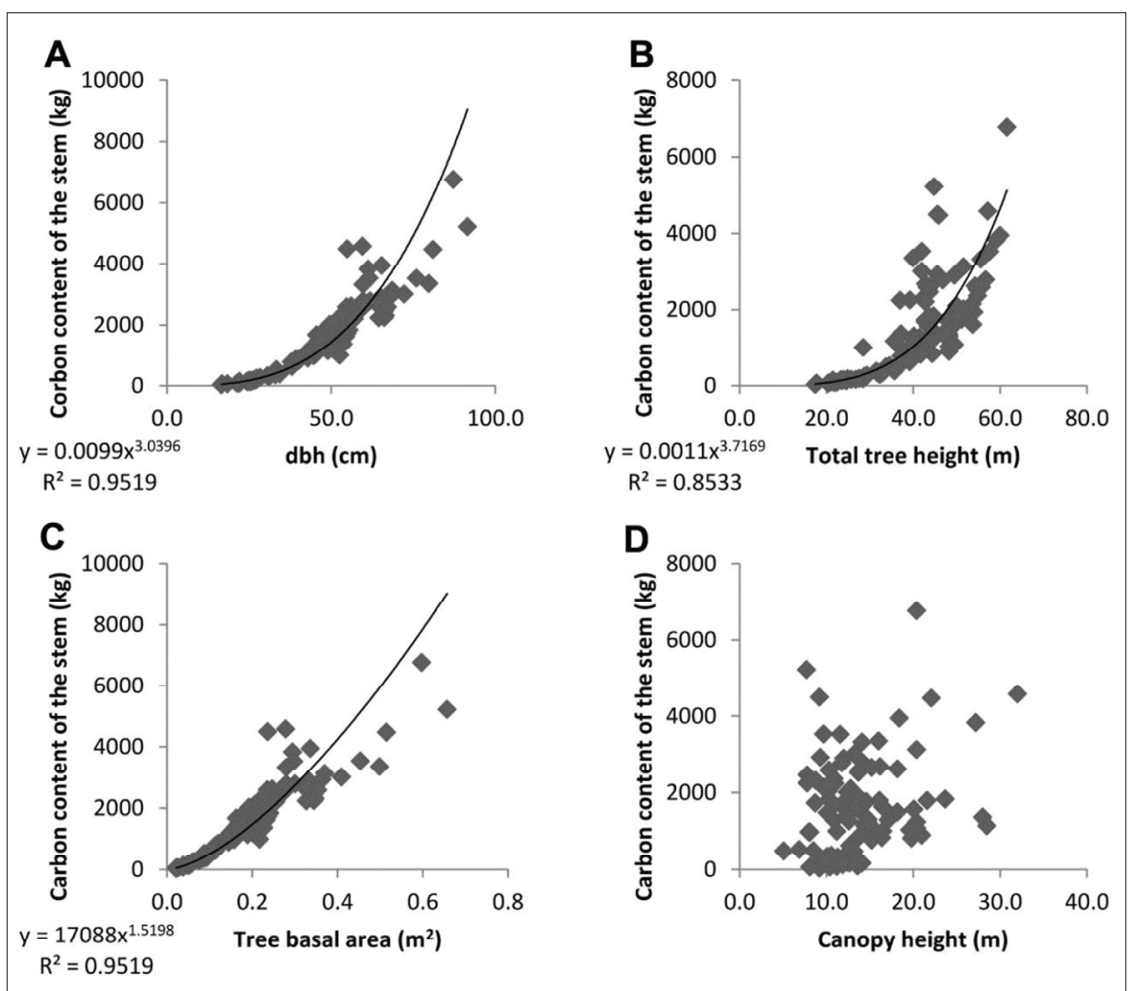

Figure 6: Distribution of the carbon content of stem with the selected explanatory variables for model construction: dbh (A); total tree height (B); tree basal area (C); canopy height (D)

Table 2: $\quad \mathrm{R}^{2}$ values and $\mathrm{p}$ values of selected models

\begin{tabular}{llc}
\hline Model* & $\mathrm{R}^{2}$ value & p value \\
\hline Model 1: $\log \mathrm{C}=-2.88+2.19 \log \mathrm{dbh}+1.40 \log$ th & $98.2 \%$ & 0.000 \\
Model 2: $\log \mathrm{C}=-1.47+5.29 \log \mathrm{g}+2.53 \log$ th & $96.0 \%$ & 0.000
\end{tabular}

* C denotes carbon content of the stem, dbh denotes diameter at breast height, th denotes total tree height and $g$ denotes tree basal area

\section{Model validation}

Model validation was carried out in order to confirm the predictability of the selected model using $25 \%$ of untouched reserved data. In model validation the normal residuals were calculated (Figure 9), which showed a random pattern indicating its starkness.

\section{Comparison of predicted total stem carbon content with actual and assumed total stem carbon content}

The carbon content predicted using the constructed model compared with $\mathrm{C}_{\text {actual }}$ and $\mathrm{C}_{\text {assumed }}$ using one way ANOVA followed by Tukey's pairwise comparison indicated that $\mathrm{C}_{\text {assumed }}$ was significantly different 


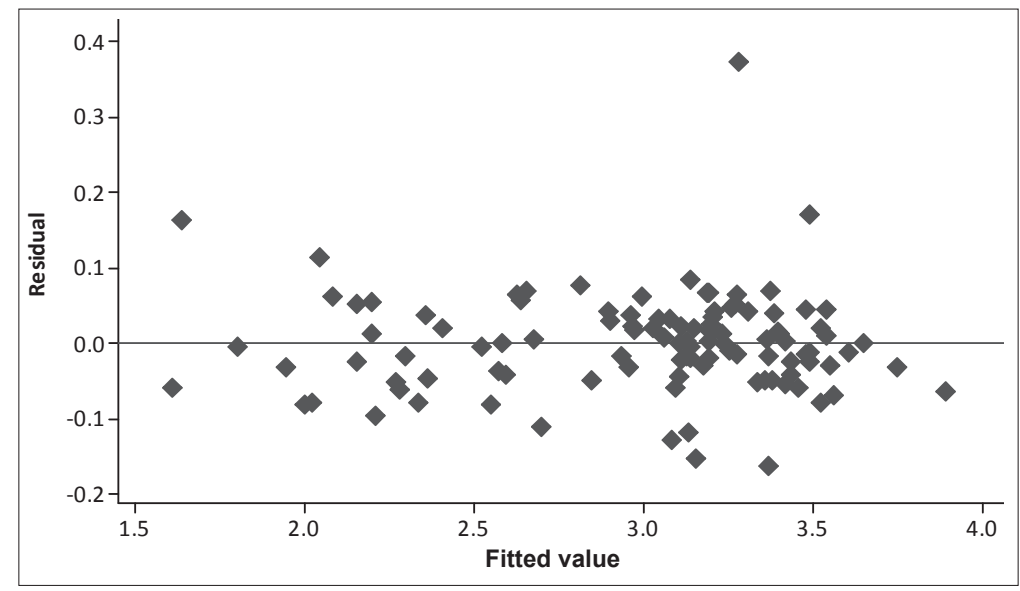

Figure 7: Residual distribution of model 1: $\log \mathrm{C}=-2.88+2.19 \log \mathrm{dbh}+1.40 \log$ tth

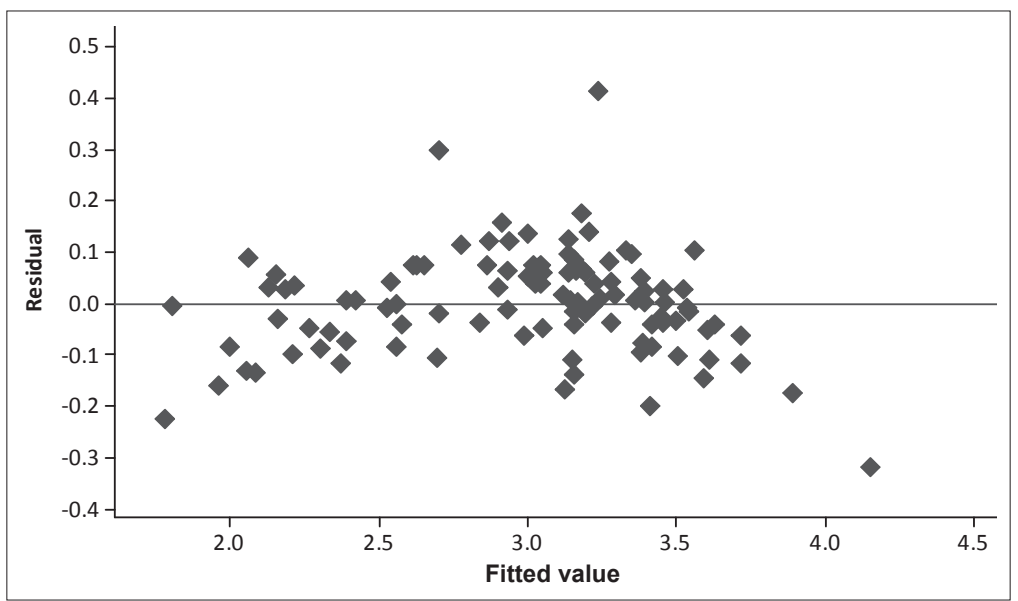

Figure 8: Residual distribution of model 2: $\log \mathrm{C}=-1.47+5.29 \log \mathrm{g}+2.53 \log$ th

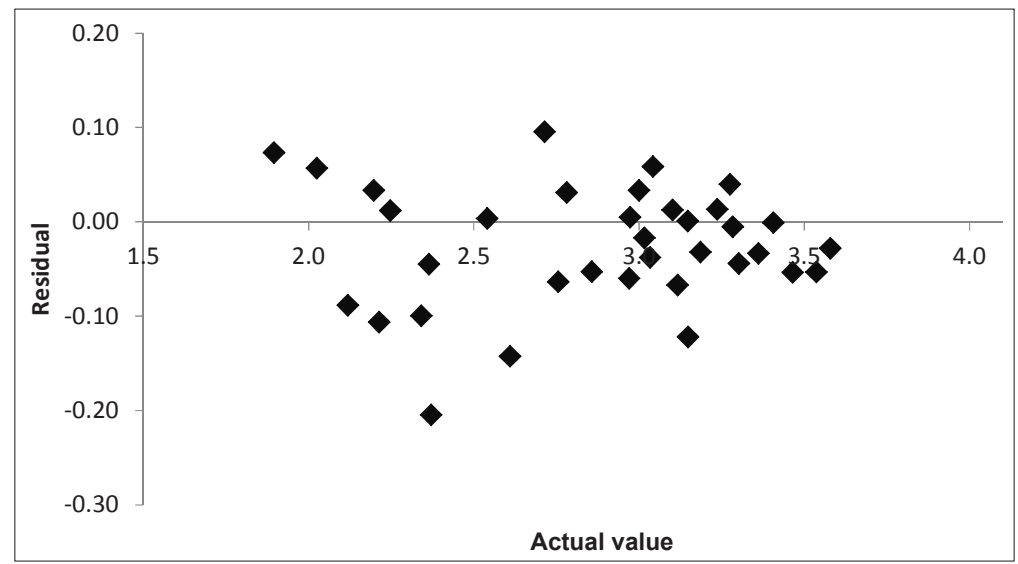

Figure 9: Graph of the residual versus actual value in model validation 
$(\mathrm{p}<0.05)$ but not significantly different from $\mathrm{C}_{\text {actual }}$. Boxplot of actual carbon content, assumed carbon content and predicted carbon content are illustrated in Figure 10.
This suggests that the constructed model is more accurate than the current practice of assumption, which can be used to estimate carbon content in E. grandis stems in Sri Lanka.

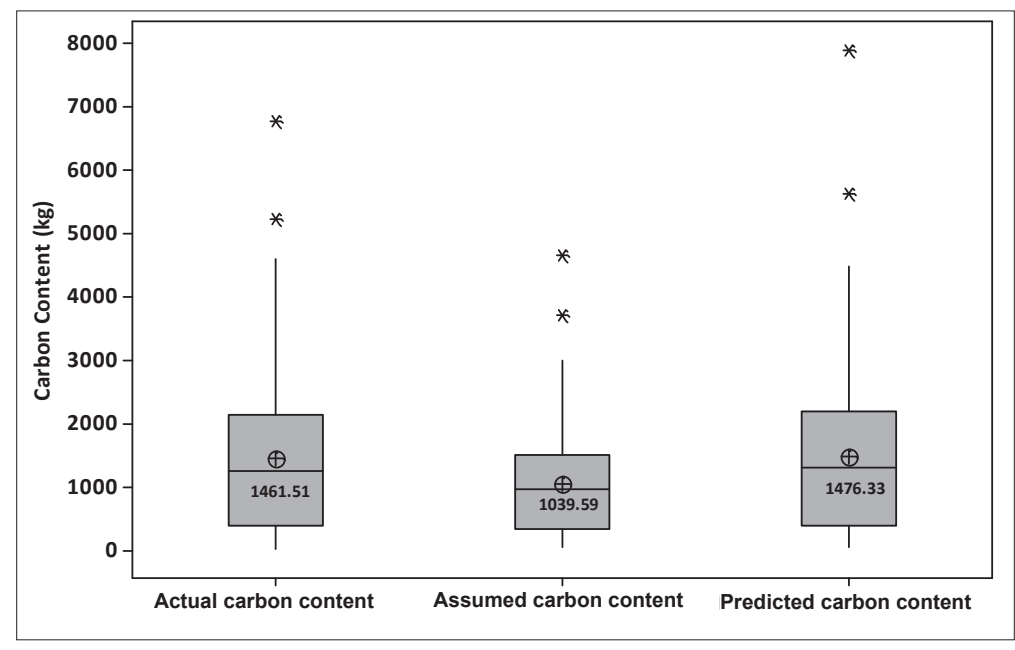

Figure 10: Boxplot of actual carbon content, assumed carbon content and predicted carbon content. $\mathrm{F}$ value $=7.00, \mathrm{p}$ value $=0.001$

Maintaining forest plantations for carbon trading has become a new trend in commercial forestry, and models to predict tree carbon content with easily measurable variables are important in this context. However, this study concluded that the assumption that $50 \%$ of dry stem biomass is carbon, which is conventionally used by forest management authorities is not accurate. A more precise way to quantify the carbon content in E. grandis stems is therefore to use species-specific empirical models derived for a particular climatic region.

The use of allometric regression models is a widely accepted tool in estimating biomass carbon all around the world (Jayakumar \& Vashum, 2012). The most important predictors used in biomass carbon calculations are diameter at breast height, total tree height, wood specific gravity and forest type or species type (Chave et al., 2005). Ullah et al. (2014) has developed several allometric models for carbon stock estimation for Acacia auriculiformis, Anthocephalus chinensis and Tectona grandis using total tree height, dbh, basal area and wood density as explanatory variables. This study further indicated $\mathrm{dbh}$ as the best predictor of tree biomass in carbon stock measurement models. In the present study out of the models constructed, model 1 was selected with tth and dbh as explanatory variables which predict the dependent variable of stem carbon content. This model constructed in the present study (log carbon content of the stem $=-2.88+2.19 \log \mathrm{dbh}+1.40 \log \mathrm{tth}$ ) is robust for predicting the stem carbon content of E. grandis. Boyce et al. (2002) and Ullah et al. (2014) have also adopted similar approaches for selecting the most appropriate predictive models for stem carbon contents of trees.

The selected two explanatory variables, $\mathrm{dbh}$ and total tree height are easy to measure in the field using forest inventory tools such as clinometer for total tree height and diameter tape for dbh. Diameter tape gives direct dbh measurement, while total tree height could be easily calculated from measurements given by the clinometer. Without further calculations, these measurements can be directly used in the model. Therefore, the two variables make estimating E. grandis stem carbon content from the model much easier. The model constructed in the present study can be useful when directed to researchers and administrators to analyse the global carbon credit in E. grandis stems, which can be helpful to develop the forestry sector in Sri Lanka. In the commercial forestry of Sri Lanka, E. grandis has a potential to be used in plantations that are maintained to mitigate global warming and carbon trading. In addition to timber value, the monetary value of carbon sequestered in stems 
provides an added value to $E$. grandis. Further, findings of this study can be used in certain managerial decisions in maintaining E. grandis plantations as well as selecting species for replanting in upcountry forest plantations. Further studies are however needed to estimate the exact carbon content sequestered in different compartments of the tree and the study can be repeated for different competitive species to make more informed decisions.

In the forestry sector, there is a tendency to grow fast growing timber species as they achieve maturity within a short time period while sequestering carbon in a considerable amount (Abayakoon et al., 2009; Markandu, 2009). As the actual carbon content of the stem is significantly higher than the conventional method ( $50 \%$ biomass is carbon), the conventional approach adopted by forest management authorities is negatively biased.

Therefore, the species-specific empirical model constructed for tropical E. grandis is more appropriate in forest carbon accounting than the conventional method of using the generic assumption. Since the constructed model uses only total tree height and dbh, which are easily measureable, the practical utility of the empirical model is significantly important. This study therefore suggests that development of such species-specific and location-specific empirical models are important for understanding biomass carbon conversion for different tropical tree species.

\section{CONCLUSION}

The major finding of this study is the significant higher value of $\mathrm{C}_{\text {actual }}$ than $\mathrm{C}_{\text {assumed }}$ based on the generic assumption of $50 \%$ of plant biomass is carbon, thus, the assumption gives an underestimate of stem carbon content in E. grandis.

From the model constructed in this study, log carbon content of the stem $=-2.88+2.19 \log \mathrm{dbh}+1.40 \log$ th, where; dbh is diameter at breast height $(\mathrm{cm})$, tth is total tree height $(\mathrm{m})$ and carbon content of the stem is the amount of total carbon per stem $(\mathrm{kg})$. This model is the most suitable model to predict stem carbon content of E. grandis in South East Asia.

Hence the results of the present study suggest to test the utilisation of generic assumption of, $50 \%$ of plant biomass is carbon, for different species and their compartments grown in different regions of the world in order to make more precise decisions regarding carbon content in plant biomass.

\section{REFERENCES}

Abayakoon A.M.C.U., Galagedara L.W. \& Nissanka S.P. (2009). Modeling carbon sequestration and evaluate the water use in Eucalyptus grandis plantations. Crop Science Student Research Abstracts 2009: 109 - 111.

Al-Amin M. \& Ullah M.R. (2012). Above- and below- ground carbon stock estimation in a natural forest of Bangladesh. Journal of Forest Science 58: 372 - 379. DOI: https://doi.org/10.17221/103/2011-JFS

Anon. (1996). Forest Inventory Manual for Sri Lanka. Forest Department, Colombo.

Boyce M.S., Nielsen S.E., Schmiegelow F.K.A. \& Vernier P.R. (2002). Evaluating resource selection functions. Ecological Modelling 157: 281 - 300.

Brown S. \& Lugo A.E. (1992). Tropical forests as sinks of atmospheric carbon. Forest Ecology and Management 5: $239-255$.

Burrows W.H., Anderson E.R., Back P.V., Carter J.O., Danaher T., Henry B.K., Hoffmann M.B., McKeon G.M., Menke N. \& Tait L.J. (2002). Growth and carbon stock change in Eucalypt woodlands in Northeast Australia: ecological and greenhouse sink implications. Global Change Biology 8(8): $769-784$.

DOI: https://doi.org/10.1046/j.1365-2486.2002.00515.x

Chakravarty S., Ghosh S.K., Suresh C.P., Dey A.N. \& Shukla G. (2012). Deforestation: causes, effects and control strategies. Global Perspectives on Sustainable Forest Management (ed. C.A. Okia). InTech Open. Available at https://www.intechopen.com/books/global-perspectiveson-sustainable-forest-management/deforestation-causeseffects-and-control-strategies.

DOI: https://doi.org/10.5772/33342

Chavan B.L. \& Rasal G.B. (2010). Sequestered standing carbon stock in selective tree species grown in university campus at Aurangabad, Maharashtra, India. International Journal of Engineering Science and Technology 2: 3003 - 3007.

Chave J., Andalo C., Brown S., Cairns M.A., Chambers J.Q., Eamus D. \& Yamakura T. (2005). Tree allometry and improved estimation of carbon stocks and balance in tropical forests. Oecologia 145(1): 87 - 99.

DOI: https://doi.org/10.1007/s00442-005-0100-x

Chave J., Réjou-Méchain M., Búrquez A., Chidumayo E., Colgan M.S., Delitti W.B., Duque A., Eid T., Fearnside P.M. \& Goodman R.C. (2014). Improved allometric models to estimate the aboveground biomass of tropical trees. Global Change Biology 20(10): 3177 - 3190.

DOI: https://doi.org/10.1111/gcb.12629

Clark D.A. (2002). Are tropical forests an important carbon sink? re-analysis of the long-term plot data. Ecological Application 12: $3-7$.

De Castro F., De Jesus R.M. \& Williamson G.B. (1993). Radial variation in the wood specific gravity of Joannesia princeps: the roles of age and diameter. Biotropica 25: $176-182$.

DOI: https://doi.org/10.2307/2389181

De Costa W.A.J.M. \& Suranga H.R. (2012). Estimation of carbon stocks in the forest plantations of Sri Lanka. Journal 
of the National Science Foundation of Sri Lanka 40(1): $9-41$.

DOI: https://doi.org/10.4038/jnsfsr.v40i1.4166

Dixon R.K., Solomon A.M., Brown S., Houghton R.A., Trexier M.C. \& Wisniewski J. (1994). Carbon pools and flux of global forest ecosystems. Science 263: 185 - 190.

DOI: https://doi.org/10.1126/science.263.5144.185

Geist H.J. \& Lambin E.F. (2002). Proximate causes and underlying driving forces of tropical deforestation: tropical forests are disappearing as the result of many pressures, both local and regional, acting in various combinations in different geographical locations. BioScience 52(2): $143-150$.

Hall P. \& Bawa K. (1993). Methods to assess the impact of extraction of non-timber tropical forest products on plant populations. Economic Botany 47(3): 234 - 247. DOI: https://doi.org/10.1007/BF02862289

Jayakumar S. \& Vashum K.T. (2012). Methods to estimate above-ground biomass and carbon stock in natural forests - a review. Journal of Ecosystem and Ecography 2: 116.

Keith H., Lindenmayer D.B. \& Mackey B.G. (2009). Reevaluation of forest biomass, carbon stocks and lessons from the world's most carbon-dense forests. Proceedings of the National Academy of Science 106(28): 11635 - 11640. DOI: https://doi.org/10.1073/pnas.0901970106

Lewis S.L. (2006). Tropical forests and the changing earth system. Philosophical Transactions 361: 195 - 210. DOI: https://doi.org/10.1098/rstb.2005.1711

Markandu T. (2009). Concept of carbon trading and its present status. Proceedings of The SAARC Symposium on Carbon Sequestration, 27 - 29 November, Thimpu, Bhutan, pp. $9-16$.

Mason E.G., Pinjuv G. \& Watt M. (2006). Quantitative validation and comparison of a range of forest growth model types. Forest Ecology and Management 236: 37 46.

DOI: https://doi.org/10.1016/j.foreco.2006.06.025

Miles P.D. \& Smith W.B. (2009). Specific gravity and other properties of wood and bark for 156 tree species found in North America. Research Note NRS-38, pp. 35. U.S. Forest Service, Newtown Square, PA, USA.

DOI: https://doi.org/10.2737/NRS-RN-38

Montagu K., Düttmer K., Barton C. \& Cowie A. (2005). Developing general allometric relationships for regional estimates of carbon sequestration-an example using Eucalyptus pilularis from seven contrasting sites. Forest Ecology and Management 204(1): 115 - 129.

DOI: https://doi.org/10.1016/j.foreco.2004.09.003

Moura-Costa P. (1996). Tropical forestry practices for carbon sequestration: a review and case study from Southeast Asia. Ambio 25: 279 - 283.

DOI: https://doi.org/10.1142/9789814261043_0014
Munasinghe G.B. \& Subasinghe S.M.C.U.P. (2011). Estimation of above ground tree biomass and carbon of Pinus caribaea (morelet). Journal of Tropical Forestry and Environment 1: $56-70$.

Muukkonen P. (2007). Generalized allometric volume and biomass equations for some tree species in Europe. European Journal of Forest Research 126: 157 - 166. DOI: https://doi.org/10.1007/s10342-007-0168-4

Pandey R., Dhall S.P. \& Kumar K. (1999). Cross validation - a tool for forest modeler. Indian Forester 125: 1224 - 1227.

Ribeiro S.C., Soares C.P.B., Fehrmann L., Jacovine L.A.G. \& von Gadow K. (2015). Above ground and belowground biomass and carbon estimates for clonal eucalyptus trees in southeast Brazil. Revista Árvore 39(2): 353 - 363. DOI: https://doi.org/10.1590/0100-67622015000200015

Rykiel E.J. (1996). Testing ecological models: the meaning of validation. Ecological Modelling 90: 229 - 244.

Sampson R.N. (1992). Forestry opportunities in the United States to mitigate the effects of global warming. Water, Air and Soil Pollution 64: 157 - 180.

DOI: https://doi.org/10.1007/BF00477100

Soares P., Skovsgaard J.P., Tome M. \& Vanclay J.K. (1995). Evaluating a growth model for forest management using continuous forest inventory data. Forest Ecology and Management 71: $251-265$.

Subasinghe S.M.C.U.P. (2007). Plantation forestry in Sri Lanka: challenges and constraints. Annual Sessions of the Institute of Biology 2007: 59 - 68.

Thomas S.C. \& Martin A.R. (2012). Carbon content of tree tissues: a synthesis. Forests 3(2): $332-352$.

DOI: https://doi.org/10.3390/f3020332

Ullah M.R., Banik G.R. \& Banik R. (2014). Developing allometric models for carbon stock estimation in eighteen year old plantation forests of Bangladesh. Jacobs Journal of Microbiology and Pathology 1: 006.

Vieilledent G., Vaudry R., Andriamanohisoa S.F.D., Rakotonarivo O.S., Randrianasolo H.Z., Razafindrabe H.N., Rakotoarivony C.B., Ebeling J. \& Rasamoelina M. (2012). A universal approach to estimate biomass and carbon stock in tropical forests using generic allometric models. Ecological Applications 22(2): 572 - 583. DOI: https://doi.org/10.1890/11-0039.1

West P.W. (2009). Tree and Forest Measurement, pp. 57 - 68. Springer, New York, USA. DOI: https://doi.org/10.1007/978-3-540-95966-3

Wilson M.V. (2007). Field Methods in Vegetation Science. Oregon State University, USA. Available at http:// oregonstate.edu, Accessed 22 April 2015.

Ximenes F.A., Gardner W.D. \& Kathuria A. (2008). Proportion of above-ground biomass in commercial logs and residues following the harvest of five commercial forest species in Australia. Forest Ecology and Management 256: 335 - 346. DOI: https://doi.org/10.1016/j.foreco.2008.04.037 